\title{
Applying Mind-Skills Training to Improve Academic Hardiness on Guidance and Counseling Students with Academic Burnout
}

\author{
Eni Rindi Antika* \\ Guidance and Counseling Department \\ Faculty of Education \\ Universitas Negeri Semarang \\ Semarang, Indonesia \\ rindi@mail.unnes.ac.id*
}

\author{
Mulawarman Mulawarman \\ Guidance and Counseling Department \\ Faculty of Education \\ Universitas Negeri Semarang \\ Semarang, Indonesia \\ mulawarman@mail.unnes.ac.id
}

\author{
Zulfa Mawadah \\ Guidance and Counseling Department \\ Faculty of Education \\ Universitas Negeri Semarang \\ Semarang, Indonesia \\ zulfamawadah422@gmail.com
}

\begin{abstract}
Student's academic achievement are often suboptimal, and burnout arises as one of its causes. Burnout can be countered when students possess academic hardiness. The present study was aimed at training students' mind skill in order to improve students' academic hardiness against burnout in the Guidance and Counseling Department of Semarang State University. This study was categorized as one group pretestPosttest experimental study. Using purposive sampling technique, forty-six students were selected as participants of the study. The data were collected using academic hardiness scale and academic burnout scale, each scale is a Likert-scale consisting of fifteen items. The data were analyzed using Paired Sample T-Test, aiming at measuring the difference in students' level of academic hardiness and academic burnout before and after the mind-skills training was conducted. The result exhibited the difference in students' level of academic hardiness and academic burnout. It could be concluded that mind-skills training is effective to improve students' academic hardiness against burnout in BK UNNES. Further, it is expected that mind-skills can be an instructional purpose and be a part of the curriculum in BK UNNES, or at least become one of the objects of study in Basic Counseling Skill subject.
\end{abstract}

Keywords-- mind-skills, academic hardiness, academic burnout

\section{INTRODUCTION}

Teaching stands as one of the main duties of lecturer in carrying out Three Pillars of Higher education (Act of the Republic of Indonesia no. 12 of 2012). One of the teaching outcomes is students academic score. Students' academic score often does not represent their ability or potential. In other words, their achievement is below their real ability. This could be caused by several factors; one of them is academic burnout.

Burnout is a notion coined by Herbert Freudenberger in 1973. In general, burnout arises and is experienced by workers. However, it is also possibly experienced by learners, including university student. Student's academic burnout refers to exhaustion due to demands of study, cynicism, and low self-efficacy [1]. Student's burnout is often caused by academic demands such as thesis, organizational activity, and parents' demand [2].

Burnout results in an adverse effect, accordingly it should be treated. Data from the Ministry of Education and Culture shows that in the 2010/2011 academic year, there were 837.213 undergraduate students. In the 2013/2014 academic year, the number of graduated students was 637.905 students. This data shows a difference between the number of enrolled students and graduated students [3]. Student's delayed graduation may be caused by various reasons. One of the classic reasons is laziness to join the lectures. This laziness may stem from burnout.

The finding of prior studies explains that student's academic hardiness declines. Hardiness can be simply defined as one's ability or strength to cope with stress [4]. Hardiness holds three characteristics, commitment, control, and challenge. Commitment refers to an individual's propensity to involve himself when doing anything. Control refers to one's ability to influence, to control, and to carry out unexpected events in his life based on his life experiences. Challenge refers to a view that changes in life are normal, not seen as a threat, yet it is considered interesting and an opportunity to develop one's self.

Following the result of the preliminary study in Guidance Counseling Department of Faculty of Education o Semarang State University (BK FIP UNNES) involving sixty students, $55 \%$ of the students' academic hardiness was categorized as low, $30 \%$ of them was categorized as moderate, and $15 \%$ of them was high. With regard to student's academic burnout, $44 \%$ of the student's academic burnout was categorized as high, $31 \%$ was categorized as moderate, and $25 \%$ was categorized as low. The data shows that student's low level of academic hardiness significantly correlates with student's academic burnout. There were 55\% of the students with low academic hardiness. Accordingly, it results in a high percentage of students with high academic burnout (44\%).

Students should possess internal skill so that they can withstand demands and pressures. By having internal skill, students are expected to have motivation to handle their difficulties and find a solution for their problems. One of the skills is mind-skills. Mind-skills can be defined as a mental process that may help students to have an efficient contextual response to a certain condition, resulting in proper problemsolving [5, 6, 7]. Mind-skills can help students to face difficult conditions due to demands and pressures so that they still possess hardiness to avoid burnout.

Grounded from the above-mentioned description, it is necessary to help students to train their mind-skills. Students with excellent mind-skills possess the proper problemsolving skill. Thus, the researchers attempted to conduct mind-skills training to improve students academic hardiness 
against burnout in the Guidance and Counseling Department of Semarang State University.

\section{METHODS}

The present study aimed to examine the effectiveness of mind-skills training in improving students' academic hardiness against burnout in Guidance and Counseling Department of Semarang State University. To this end, this study employed experimental method. This study was aimed at finding out the difference in students' level of academic hardiness and burnout before and after the intervention, i.e., mind-skills training, was given. Accordingly, the present study employed one group pretest Posttest experimental research design.

The population of the study was students of BK FIP UNNES. Forty-six students were purposively selected as participants of the study under the criteria. The criteria were that the students' level of academic hardiness was low, and students' level of academic burnout was high.

Academic hardiness and academic burnout scales were deployed for the purpose of data collection. Academic hardiness scale was developed by researchers following Kobasa, Maddi, and Khan's concept [8]. Based on the concept, the blueprint was developed with the indicators of hardiness involve: commitment, control, challenge. The instrument of academic hardiness contained fifteen items with four-point likert scale ( 1 = highly disagree; $4=$ highly agree). For academic burnout scale, it was developed by adapting Schaufeli's (2002) Burnout Inventory-Student Survey, this scale consists of three indicators, namely: Exhaustion, cynicism, and inefficacy. Through backtranslation process, this instrument contains fifteen items with four-point likert scale ( 1 = highly disagree; $4=$ highly agree)

For the purpose of hypothesis testing, the data were analyzed using Paired Sample T-Test. T-test was employed to examine the difference in student's level of academic hardiness and burnout before and after the mind-skills training was given.

\section{RESULT AND DISCUSSION}

Results

The result of the study shows a difference in students' academic hardiness and burnout in BK UNNESS before and after mind-skills training was conducted. Table 1 shows the result of the study in detail.

Table 1. Pretest and Posttest Result of Mind-skills Training

\begin{tabular}{ccccccc}
\hline & Pre-Test & Post-Test & \multicolumn{2}{c}{$\begin{array}{c}\text { Paired Samples } \\
\text { Correlations }\end{array}$} & \multicolumn{2}{c}{$\begin{array}{c}\text { Paired } \\
\text { Samples Test }\end{array}$} \\
\cline { 2 - 7 } & Mean & Mean & Correlation & Sig & Mean & Sig \\
\hline AH & 33.13 & 41.89 & 0.58 & 0.00 & 8.76 & 0.00 \\
BA & 37.87 & 28.48 & 0.53 & 0.00 & 9.39 & 0.00 \\
\hline
\end{tabular}

Table 1 above shows that students' level of academic hardiness before participating in mind-skills training was 33.13. The score was improved after they participated in mind-skills training. Their average score of academic hardiness after participated in mind-skills training was 41.89 . This result is relevant with average score of students' academic hardiness before and after mind-skills training was given (8.76). The correlation between the level of academic hardiness before and after the mind-skills training was given was 0.58 with $\mathrm{Sig}$. value of 0.00 (Sig. $0.00<0.05$ ). This shows that the correlation between the level of academic hardiness before and after receiving mind-skills training was strong and significant. The participants of mind-skills training obtained the Sig. value of 0.00 . Because of Sig. $0.00<0.05$, it could be concluded that $\mathrm{Ha}$ is accepted, it means that mindskills training can improve students' academic hardiness in BK UNNES.

Table 1 shows that the average level of student's burnout was 37.87 , and 28.48. This difference shows that there is a reduction in students' academic burnout before and after the mind-skills training was conducted. The score is relevant to the average score of students' level of academic burnout (9.39). This result supports that mind-skills training can lower students' level of burnout. The correlation score of academic burnout before and after the mind-skills training was conducted was 0.53 with Sig. value of 0.00 (Sig. $0.00<0.05$ ). It means that there is a strong and significant correlation between students' academic burnout before and after mindskills training. Forty-six participants of mind-skills training hold Sig. value of 0.00. It was found that Sig. $0,000<0,05$, accordingly, mind-skills training may lower students' academic burnout in BK UNNES.

\section{Discussion}

In general, it could be concluded that mind-skills training affect students' improvement of academic hardiness against burnout in BK FIP UNNES. In other words, mind-skills training is effective to improve students' academic hardiness and lower student's academic burnout in BK FIP UNNES. This result is relevant to the study finding that mind-skills internalization in Guidance and Counseling Department students may improve their basic counseling communication skill. It means that mind-skills are one of the internal skills that can be trained and can result in students' positive changes [9].

As it is previously stated, mind-skills are as a mental process that may help students to have an efficient contextual response to a certain condition, resulting in proper problemsolving $[5,6,7]$. Students with proper mind-skills tend to be persistent and strong as the characteristic of hardiness, i.e., Commitment, control, and challenge [8]. Mind-skills help students to be committed, have control, and ready to face a challenge, resulting in their academic performance.

Through mind-skills, students are trained to set a helpful rule, perception, self-talk, visual image, explanation, and expectation $[5,6,7]$. These six components of mind-skills are activities occurring in one's cognition. Accordingly, it is called internal skill. Each component of the skills affect an individual's behavior and feeling, as it has been proven by previous studies.

Result of studies on 'rule' concluded that a rule set by an individual is aimed to guide his behaviors $[10,11,12,13,14]$. Therefore, students need to possess helpful skills related to his study. Through mind-skills training, students are directed to develop flexible and preferential rules. Thus, if the first rule cannot be met, students are prevented from stress.

Some previous studies also examined about perception. These studies explained that one's perception is used as the basis to predict other's or the surroundings' behavior $[15,16$, 17]. Perception is closely associated with the stress an individual experiences. Mind-skills training helps students to 
have a broad perspective so that they do not hurriedly make a conclusion without concrete evidence. This may prevent students from dimensions of academic burnout, particularly depersonalization.

Studies on self-talk found that an individual's self-talk directs his acts $[18,19,20]$. By having the skill to develop helpful self-talk, students are trained to provide themselves positive instructions. This is closely related to control as one of the characteristics of hardiness. It is also closely associated with the other three dimensions of academic burnout and characteristic of hardiness.

Some scholars conducted studies on the visual image. Their studies explained that visual image is significantly helpful for an individual in carrying out his activities. It occurs because an individual is capable of improving his mind-skills when receiving information in the form of sentence and visualization through images [21, 22, 23]. Visual image affects information processing, resulting in indepth understanding. Accordingly, when students are capable of developing helpful visual image during their study, they may fully involve themselves in their academic activities. For instance, a helpful visual image allows students to understand the materials presented by their lecturers more easily. The form of a helpful visual image can be, for instance, students imagine a concrete example of lecturer's explanation.

With regard to explanation, studies found that the structure of explanation within one's cognition contains a long analytical system about reasons. That reason is the form of belief, affecting the individual's action. When an individual can provide explanation of his act, everything he does can be accounted [24, 25]. Mind-skills training help students to create an explanation containing personal reasons. Thus, students do not easily blame other individuals and situations when facing something. Skills to develop explanation may train students to be responsible for their behavior.

Studies on expectation explain that expectation holds a pivotal role in how an individual plans his life and achieves the determined goal. An individual with positive expectation exhibits positive behavior or performance as well [26, 27, 28]. Creating expectation may lead students to be an optimistic and realistic person. Expectation is considered helpful when it complies with one's competence and skills. Likewise, other components of mind-skills, expectation also affect the students' characteristics of academic hardiness and components of academic burnout, particularly inefficacy. Mind-skills training may reduce inefficacy since the students are directed to develop an expectation that fits their potential, not the excessive ones.

Mind-skills training help students to manage their feeling and thought so that they can control their act [9]. Mind-skills training encourages students to be persistent, strong, and hardy. This highly affects students' attempts in undergoing his study so that they are prevented from academic burnout. Mind-skills help students to (1) Set a flexible and preferential rule; (2) be open-minded and multi-perspective; (3) perform positive self-instruction; (4) develop a constructive visual image; (5) not easily blame situation and other individuals; and (6) create a realistic expectation [9].

\section{CONCLUSION}

The present study concludes that mind-skills training may enhance students' academic hardiness against burnout in BK UNNES. There is a difference in students' level of academic hardiness before and after mind-skills training is applied. Thus, mind-skills training positively and is effective to improve students' academic hardiness and lower student's academic burnout in BK FIP UNNES. In other words, when students have good mind-skills, they will have high academic hardiness. The high academic hardiness of students can reduce the level of academic burnout. Therefore, mind-skills need to be taught, trained, and internalized so that it can be integrated in students. Further, this study calls for a follow-up from the department to make mind-skills as an instructional effect. It would be advantageous if mind-skills become part of the Curriculum of BK FIP UNNES, or at least become the material taught in one of the subjects. The subject that closely related to mind-skills is Basic Counseling Skill.

\section{ACKNOWLEDGMENT}

The researchers would like to express their gratitude to all parties involved in this study. The Ministry of Research, Technology and Higher Education which has provided DIPA (Budget Implementation Checklist) funds for researchers at Universitas Negeri Semarang. The lecturers of BK FIP UNNES who have been great discussion partners and encouraged the researchers to conduct this study. The students of BK FIP UNNES who participated in this study, especially the participants of the training who were willing to participate the training. The researchers' parents, husband, and wife who always provide their supports for the researchers. And all parties the researchers cannot mention one by one. The researchers hope that experience obtained during this study triggers the researchers to always do selfdevelopment.

\section{REFERENCES}

[1] Zhang, Y., et al. (2007). Perfectionism, Academic Burnout and Engagement among Chinese Collage Students: A Structural Equation Modeling Analysis. Journal of Personality as Individual Differences. 43, 1529-1540.

[2] Lin, S.H., et al. (2014). Life Stress and Academic Burnout. Journal of Active Learning in Higher Education. 15(1) 77-90.

[3] Purnama, dkk. (2017). Academic Burnout Mahasiswa. Unpublished Manual Book. Malang: BK FIP UM.

[4] Nofianti, dkk. (2017). Academic Hardiness Siswa. Unpublished Manual Book. Malang: BK FIP UM.

[5] Jones, R. N. (2003a). Basic Counselling Skills: A Helper's Manual. London: Sage Publications.

[6] Jones, R. N. (2003b). Introduction to Counseling Skills. Text \& Activities. London: Sage Publication.

[7] Jones, R. N. (2005). Introduction to Counselling Skills: Text and Activities. London: Sage Publications.

[8] Kobasa, S. C, Maddi, S. R, \& Khan, S. (1982). Hardiness and Health: A Prospective Study. American Psychological Association.

[9] Antika, E. R. (2017). Internalisasi Mind-skills Mahasiswa BK dalam Praktik Keterampilan Dasar Komunikasi melalui Strategi supervisi Terbimbing.Unpublished Thesis. Malang: Pascasarjana BK UM.

[10] Danforth, J. S., et al. (2014). The Development of Comorbid Conduct Problems in Children with ADHD: An Example of an Integrative Developmental Psychopathology Perspective. Journal of Attention Disorders, 1-6.

[11] Harwood, L. E., et al. (2016). Improving Vascular Access Outcomes: Attributes of Arteriovenous fistula Cannulation Success. Clinical Kidney Journal, 9: 303-309.

[12] Hastings, R. P. \& Brown, T. (2000). Functional Assessment and Challenging Behaviors: Some Future Directions. Journal of The Association for Persons with Severe Handicaps, 25: 229-240. 
[13] Schreiber, J. \& Dixon, M. R. (2001). Temporal Charactenstics of Slot Machine Play in Recreational Gamblers. Psychological Reporfs, 89: 67-72.

[14] The Authors. (2015). Social Anxiety Disorder. Journal of Psychology, $0: 1-8$.

[15] Gervais, W. M. (2013). Perceiving Minds and Gods: How Mind Perception Enables, Constrains, and is Triggered by Belief in God. Perspectives on Psychological Science Journal, 8: 380.

[16] Schellenberg, S. (2007). Action and Self-Location in Perception. Journal of Mind, 116: 463.

[17] Sivberg, B. (1998). Self-Perception and Value System as Possible Predictors of Stress. Journal of Nursing Ethics, 5: 2.

[18] Hatzigeorgiadis, A., et al. (2011). Self-Talk and Sports Performance: A Meta-Analysis. Perspectives on Psychological Science Journal, 6: 348-356.

[19] Stamou, E., et al. (2007). The Efffect of Self-Talk on The Penalty Execution in Goalball. British Journal of Visual Impairment, 25: 233.

[20] Tovares, A. V. (2010). Managing the Voices: Athlete Self-Talk as a Dialogic Process. Journal of Language and Social Psychology, 29: 261-277.

[21] Bailey, N. M. \& Harken, M. V. (2014). Visual Images as Tools of Teacher Inquiry. Journal of Teacher Education, 65: 241-260.

[21] Chapman, M. V. et al. (2013). How Images Work: An Analysis Of a Visual Intervention Used to Facilitate a Difficult Conversation and
Promote Understanding. Journal of Qualitative Social Work, 13 (4): 456-476.

[22] Domke, et al. (2002). The Primes of Our Times? An Examination of The 'Power' of Visual Images. Journal of Psychology, 3 (2): 131-159.

[23] Ouzilou, O. (2014). Epistemic Context and Structural Explanation of Belief. Philosophy of the Social Sciences Journal, 44 (5): 630-645.

[24] Stueber, K. R. (2012). The Causal Autonomy of Reason Explanations and How Not to Worry about Causal Deviance. Philosophy of the Social Sciences Journal, 43(1): 24-45.

[25] Deegan, M. P., et al. (2015). Positive Expectations Encourage Generalization From a Positive Intergroup Interaction to Outgroup Attitudes. Journal of Society for Personality and Social Psychology, 41 (1): 52-65.

[26] Kline, C. et al. (2015). An Exploratory Study of ExpectationImportance-Performance Analysis with Cultural Tourists in Havana, Cuba. Journal of Tourism and Hospitality Research, 16 (1): 19-34.

[27] Meyer, L. H., \& Sanklecha, P. (2014). How Legitimate Expectations Matter in Climate Justice. Journal of Politics, Philosophy \& Economics, 13 (4): 369-393.

[28] Purwaningrum, R. (2013). Internalisasi Mind-skills Mahasiswa Bimbingan Konseling (BK) melalui Experiential Learning. Unpublished Thesis. Malang: Pascasarjana BK UM. 